\title{
NON-ENZYMATIC ANTIOXIDANT FROM APPLE SNAIL (Pomacea maculata) EXTRACT
}

\author{
KHALIDA KHALIL ${ }^{1}$, SYARUL NATAQAIN BAHARUM ${ }^{2}$, SHAZRUL FAZRY ${ }^{3}$, \\ NIK MARZUKI SIDIK ${ }^{4}$ and FAREED SAIRI ${ }^{* *}$ \\ ${ }^{1}$ Department of Biological Sciences and Biotechnology, Faculty of Science and Technology, \\ Universiti Kebangsaan Malaysia, 43600 Bangi, Selangor, Malaysia \\ ${ }^{2}$ Institute of Systems Biology, Universiti Kebangsaan Malaysia, 43600 Bangi, Selangor, Malaysia \\ ${ }^{3}$ Tasik Chini Research Center, Faculty of Science and Technology, \\ Universiti Kebangsaan Malaysia, 43600 Bangi, Selangor, Malaysia \\ ${ }^{4}$ Fakulti Industri Asas Tani, Universiti Malaysia Kelantan, Kampus Jeli, \\ 17600 Jeli, Kelantan, Malaysia \\ "E-mail: fareed@ukm.edu.my
}

Accepted 6 December 2020, Published online 31 December 2020

\begin{abstract}
Pomacea sp. is a freshwater gastropod that is capable of withstanding oxidative stress during extreme environmental changes. The snail enzymatic oxidative responses have already been elucidated through biochemical, transcriptomics, and proteomics analysis. However, their non-enzymatic oxidative responses have yet to be elucidated. Therefore, this study aims to characterize the antioxidant activity and identify the non-enzymatic antioxidant compounds from Pomacea maculata. To address the aims, a polar and non-polar extraction of snail-whole body extract was conducted using methanol and chloroform, respectively. The antioxidant activity of both extracts was elucidated by Folin Ciocalteau (FC), DPPH, and reducing power assay. LCMS/MS was then used to profile both extracts. The results demonstrated that the crude methanol extract (CME) contains a higher antioxidant capacity $\left(\mathrm{FC}=43.22 \pm 3.02 \mathrm{mg} \mathrm{GAE} / \mathrm{g}\right.$ extract, $\mathrm{DPPH} \mathrm{IC}_{50}=0.073 \mathrm{mg} / \mathrm{mL}$, and reducing the power of methanol and chloroform extract are $0.361 \pm 0.07$ and $0.051 \pm 0.003$ respectively). Profiling of the snail metabolites by LCMS/MS from both extracts resulted in the identification of uric acid and phenolic compounds. The former was detected at the highest intensity in CME followed by crude chloroform extract (CCE). The phenolic compounds, however, were hypothetically identified as plant metabolites. Therefore, the study suggested that antioxidant activity exhibited by $P$. maculata extracts were due to non-enzymatic compounds such as uric acid and phenolic compounds originated from the animal's metabolic activity and plants, respectively.
\end{abstract}

Key words: Apple snail metabolite, non-enzymatic antioxidant, LC-MS/MS, phenolic compound, freshwater mollusc, oxidative stress

\section{INTRODUCTION}

Free radicals are generated endogenously by the cell's mitochondrial activity and cellular processes or exogenously through radiation, heavy metal, pesticides, and drugs (Phaniendra et al., 2015). The formation of free radicals is regulated by a series of complex antioxidant defense mechanisms that involve enzymatic and non-enzymatic antioxidants. Excessive free radicals or antioxidant agent deficiency contribute to oxidative stress condition that cause DNA damage, protein oxidation, and lipid peroxidation (Murugan \& Parimelazhagan, 2014).

\footnotetext{
* To whom correspondence should be addressed.
}

In mollusks, oxidative stress caused by the overproduction of free radicals is associated with environmental stress (extreme temperature, water availability), food limitation, and dormancy (aestivation) (Hayes et al., 2012; Giraud-billoud et al., 2013). For example, the over a generation of reactive oxygen species (ROS) were caused by reoxygenation during arousal after aestivation (Hermes-Lima \& Storey 1995). To minimize the adverse effect of ROS during reoxygenation, pulmonates such as Theba pisana depends on nonenzymatic antioxidant (endogenous antioxidant) while Pomacea canaliculata deploy both enzyme and non-enzymatic defense mechanisms (Giraudbilloud et al., 2013; Bose et al., 2016). 
In addition to endogenous antioxidant production such as uric acid and glutathione (Bose et al., 2016; Vassilev et al., 2020), novel antioxidant compounds were also found in mollusks. Previous studies had found 6-(diphenylphosphoryl)-3,4bis(diisopropylamino)-5-pyrrolidino pyridazine and $3,3,4,4$-tetracyano-5,6-diphenyl-2-(cyclohexylimino)-2,3,4,5-tetrahydropyridine from Turbo bruneus (Tamil Muthu and Selvaraj 2015) and 6-bromo-5-hydroxy indole, 6 - bromo-4, 7 dihydroxyindole and 6-bromo-4,5-dihydroxyindole from Drupella fragum (Ochi et al., 1998). Antioxidant activity was also demonstrated in extracts from the snail eggs (Dreon et al., 2004), the flesh of Pila ampullacea (Haslianti et al. 2017), Pila virens (Gayathri et al., 2017), and visceral extracts (Pachaiyappan et al., 2014).

Pomacea maculata is regarded as the largest freshwater snail that originated from South America (Hayes et al., 2012). The snail was initially introduced to Asian countries as a food source for humans due to its abundance of flesh and high protein content (Haslianti et al., 2017). However, poor demand from the local market caused the snail to be disposed of irresponsibly. Subsequently, the snail established itself as a pest and invaded local wetlands to feed on native plants (Burlakova et al., 2009; Baker et al., 2010). To date, snails are regarded as highly invasive pests that threaten the agriculture industry and local wetlands (Salleh et al., 2012). In Malaysia, apple snails have infested almost 20,000 ha of rice-growing areas and have threatened the livelihoods of farmers. In 2010, the costs associated with apple snail damage were estimated at RM82 million (the US\$28 million) (Hussain et al., 2017). Endogenous and exogenous antioxidants are imperative to snail survival and elucidating their presence in snails may provide a novel solution to facilitate pest management. Although regulation of enzymatic antioxidant has been described by Giraud-billoud et al. (2013), nonenzymatic antioxidant has yet to be reported intensively. Hence, this study was conducted to evaluate the non-enzymatic antioxidant in $P$. maculata extracted with methanol (polar) and chloroform (non-polar).

\section{MATERIALS AND METHODS}

\section{Standards and reagent}

Ascorbic acid and gallic acid standards were purchased from Sigma (St. Louis, MO, USA). 2,2diphenyl-1-picrylhydrazyl (DPPH) was supplied by Alfa Aesar (Ward Hill, MA, USA). Methanol and chloroform were obtained from Univar (Ajax Finechem, Australia) and Merck (Darmstadt, Germany), respectively.

\section{Sampling and sample preparation}

Apple snail was collected in November 2017 from Selangor, Malaysia ( $2^{\circ} 53^{\prime} 0^{\prime \prime}$ North, $101^{\circ} 46^{\prime}$ $0 "$ East) and identified as Pomacea maculata based on their pink egg, $90^{\circ}$ open-ended corner of the shell and a rounded shell form (Hayes et al., 2012). The captured snails were then washed with sterilized distilled water. The whole body was removed from the shell and frozen using liquid nitrogen. The samples were then kept at $-80^{\circ} \mathrm{C}$ until extraction.

\section{Crude extracts preparation}

Preparation of the crude extracts was performed in methanol/chloroform according to Overy et al., (2005) with modification. Briefly, the whole body of P. maculata (without shell) was frozen using liquid nitrogen, weighed, and then powdered using mortar and pestle. Then, a cold extraction medium comprising of water/chloroform/methanol (8:20:47, by volume), was added to a cooled tube with the powdered sample and left on ice for $30 \mathrm{~min}$. The samples were then centrifuged at $15,000 \times \mathrm{g}$ for 4 min to form separate layers. The upper layer (polar extract) that consists of aqueous metabolites were separated and the lower layer (non-polar extract) was subjected to a secondary extraction by adding $4 \mathrm{~mL}$ of water per gram of sample. After that, both upper and lower layer extracts were concentrated using a rotary evaporator and dried using a speed vacuum at $37^{\circ} \mathrm{C}$, and kept at room temperature.

\section{Folin Ciocalteu assay}

The measurement of each extracts by Folin Ciocalteu assay (Singh et al., 2016) were evaluated as the total reducing capacity (Magalhaes et al., 2008). The crude extract from both methanol and chloroform extraction was diluted to $1.0,0.5$, and $0.25 \mathrm{mg} / \mathrm{mL}$ with water. A reaction mixture consisting of $30 \mu \mathrm{L}$ of diluted extracts and $150 \mu \mathrm{L}$ Folin Ciocalteu reagent $(1: 11 \mathrm{v} / \mathrm{v}$ in water) was prepared in triplicates. The reaction mixture was incubated for $5 \mathrm{~min}$ at $25^{\circ} \mathrm{C}$. After $5 \mathrm{~min}, 120 \mu \mathrm{L}$ of $75 \mathrm{~g} / \mathrm{L}$ sodium bicarbonate was added to the reaction mixture and incubated at $25^{\circ} \mathrm{C}$ for $90 \mathrm{~min}$. After that, the absorption was measured at $725 \mathrm{nM}$ using a microplate reader. A standard curve based on Gallic acid concentration $(250-7.85 \mu \mathrm{g} / \mathrm{mL})$ was prepared and the total reducing capacity was determined and expressed as milligram gallic acid per gram of extract.

\section{Free radical scavenging assay \\ (2,2-diphenyl-1-picrylhydrazyl; DPPH)}

The crude methanol and chloroform extracts were screened for free radical scavenging activity using DPPH free radical scavenging assay according to Mensor et al. (2001) with slight modification. The samples $(15.7,31.3,62.5,125,250$ and 500 
$\mu \mathrm{g} / \mathrm{mL})$ and ascorbic acid $(1.57,3.13,6.25,12.5,25$ and $50 \mu \mathrm{g} / \mathrm{mL}$ ) were diluted using methanol. The reaction mixture was prepared by adding $125 \mu \mathrm{L}$ sample of various concentrations and $50 \mu \mathrm{L}$ of 0.3 mM DPPH solution. A total of $50 \mu \mathrm{L}$ methanol and $125 \mu \mathrm{L}$ samples at various concentrations were prepared for blank and $50 \mu \mathrm{L}$ of $0.3 \mathrm{mM}$ DPPH and $125 \mu \mathrm{L}$ methanol were used as a control. The mixtures were then incubated in the dark at room temperature for $30 \mathrm{~min}$. Consequently, the absorption was measured at $517 \mathrm{nM}$ wavelength and converted to the percentage of antioxidant activity (AA) using the following formula:

$\mathrm{AA} \%=100-\{[($ Abs sample - Abs blank $) \times 100] \div$ Abs control $\}$

\section{Reducing power assay}

The reducing power of both extracts was evaluated according to (Singh et al., 2016) with slight modification. Methanol and chloroform extracts were diluted to different concentrations $(1-0.25 \mathrm{mg} / \mathrm{mL})$ and ascorbic acid concentration $(0.125-0.008 \mathrm{mg} / \mathrm{mL})$ were prepared in $0.25 \mathrm{~mL}$ solution with phosphate buffer $(500 \mu \mathrm{L}, 0.2 \mathrm{M}, \mathrm{pH}$ 6.6) and potassium ferricyanide $\left[\mathrm{K}_{3} \mathrm{Fe}(\mathrm{CN})_{6}\right](500$ $\mu \mathrm{L}, 10 \mathrm{mg} / \mathrm{mL}$ ). The mixture was incubated at room temperature $\left(25^{\circ} \mathrm{C}\right)$ for $20 \mathrm{~min}$. After incubation, 500 $\mu \mathrm{L}$ of $10 \%$ trichloroacetic acid (TCA) solution was added to each tube and the mixture was centrifuged at $8000 \mathrm{rpm}$ for $10 \mathrm{~min}$. A total of $100 \mu \mathrm{L}$ of clear supernatant was mixed with an equal amount of sterilized distilled water, $20 \mu \mathrm{L}$ of ferric chloride $(0.1 \% \mathrm{w} / \mathrm{v})$ solution was added and absorbance was recorded at $700 \mathrm{nM}$. Phosphate buffer was used as a control. The effective concentration providing 0.5 of absorbance $\left(\mathrm{EC}_{50}\right)$ was calculated from the graph of absorbance at $700 \mathrm{nM}$ against extract concentration.

\section{LC-MS/MS profiling}

A total of $0.1 \mathrm{~g}$ of ground $P$. maculata (whole body without shell) was used to prepare CME and CCE according to (Overy et al., 2005) while the profiling of both extracts were performed on Mamat et al. (2018). Briefly, chromatography separation was performed on the Thermo Scientific C18 column (AcclaimTM Polar Advantage II, 3 x 150 $\mathrm{mM}, 3 \mu \mathrm{M}$ particle size) on an UltiMate 3000 UHPLC system (Dionex). Gradient elution was performed at $0.4 \mathrm{~mL} / \mathrm{min}$ at $40^{\circ} \mathrm{C}$ using water + $0.1 \%$ Formic Acid (A) and 100\% acetonitrile (B). One microliter of the sample was injected into the column and the run was performed for $22 \mathrm{~min}$. The gradient started at 5\% B (0-3 min); $80 \%$ B (3-10 $\mathrm{min}) ; 80 \% \mathrm{~B}(10-15 \mathrm{~min})$ and $5 \% \mathrm{~B}$ (15-22 $\mathrm{min})$. High-resolution mass spectrometry was carried out using a MicroTOF QIII Bruker Daltonic with an ESI positive ionization based on the following settings:
- capillary voltage: $4500 \mathrm{~V}$; nebulizer pressure: 1.2 bar; drying gas: $8 \mathrm{~L} / \mathrm{min}$ at $200^{\circ} \mathrm{C}$. The mass range recorded was $50-1000 \mathrm{~m} / \mathrm{z}$.

Data analysis of CME and CCE metabolite profile

The molecular ions mass data provided by the TOF analyzer were processed by Compass Data Analysis software version 4.2 (Bruker Daltonik $\mathrm{GmbH}$ ). The $\mathrm{m} / \mathrm{z}$ values of compounds were referred to the METLIN database to putatively identify each compound present in both profiles.

\section{Statistical analysis}

Results were presented as mean \pm standard deviation from triplicates $(n=3)$ and statistical significance between the two solvents was analysed using t-test with p-value less than 0.05 using GraphPad Prism 6.

\section{RESULTS}

In this study, the presence of total reducing capacity in both methanol and chloroform crude extracts of $P$. maculata has confirmed in the Folin Ciocalteu assay. As summarised in Table 1, crude methanol extract (CME) from P. maculata displayed higher total reducing capacity than crude chloroform extract (CCE) with a value of $43.37 \pm 3.02 \mathrm{mg}$ $\mathrm{GAE} / \mathrm{g}$ extract and $13.62 \pm 1.92 \mathrm{mg} \mathrm{GAE} / \mathrm{g}$ extract, respectively.

The free radicals scavenging ability of CME and CCE was measured using DPPH assay. In this study, CME demonstrated a higher scavenging activity than CCE towards DPPH radical. In Table 2, the scavenging activity of CME was 1000 times higher than CCE ( $\mathrm{IC}_{50}: 0.073 \mathrm{mg} / \mathrm{mL}$ and $78.16 \mathrm{mg} / \mathrm{mL}$, respectively). Higher scavenging activity was indicated by a lower $\mathrm{IC}_{50}$ value.

In addition to scavenging activity, the CME also demonstrated higher reducing power ability $(\mathrm{p}<0.05)$ than CCE. As depicted in Figure 1, CME reducing power ability increased according to the extract concentration while CCE maintained a low

Table 1. The antioxidant activity of crude methanol and chloroform extracts of $P$. maculata measured by Folin Ciocalteu and DPPH

\begin{tabular}{lcc}
\hline & \multicolumn{2}{c}{ Antioxidant Activity } \\
\cline { 2 - 3 } Samples & $\begin{array}{c}\text { Folin Ciocalteau Assay } \\
(\mathrm{mg} \mathrm{GAE} / \mathrm{g} \text { extract })\end{array}$ & $\begin{array}{c}\mathrm{DPPH} \\
\text { Assay }\end{array}$ \\
\cline { 2 - 3 } & $\begin{array}{c}\text { Concentration } \\
(\mathrm{mg} / \mathrm{mL})\end{array}$ & $\begin{array}{c}\mathrm{IC}_{50} \\
(\mathrm{mg} / \mathrm{mL})\end{array}$ \\
\hline Methanol Extract & $43.37 \pm 3.02$ & 0.073 \\
Chloroform Extract & $13.62 \pm 1.92$ & 78.165 \\
Ascorbic Acid & - & 0.008 \\
\hline
\end{tabular}


Table 2. The DPPH scavenging activity of crude methanol and chloroform extracts of different mollusks

\begin{tabular}{|c|c|c|c|}
\hline \multirow{3}{*}{ Samples } & \multicolumn{2}{|c|}{ DPPH scavenging activity } & \multirow{3}{*}{ References } \\
\hline & Methanol Extract & Chloroform Extract & \\
\hline & $\mathrm{IC}_{50}(\mathrm{mg} / \mathrm{mL})$ & $\mathrm{IC}_{50}(\mathrm{mg} / \mathrm{mL})$ & \\
\hline P. maculata & 0.073 & 78.165 & Current study \\
\hline P. ampullacea & 0.111 & 0.997 & (Haslianti et al., 2017) \\
\hline L. littorea & 0.78 & - & (Borquaye et al., 2016) \\
\hline G. paradoxa & 0.37 & - & (Borquaye et al., 2016) \\
\hline
\end{tabular}

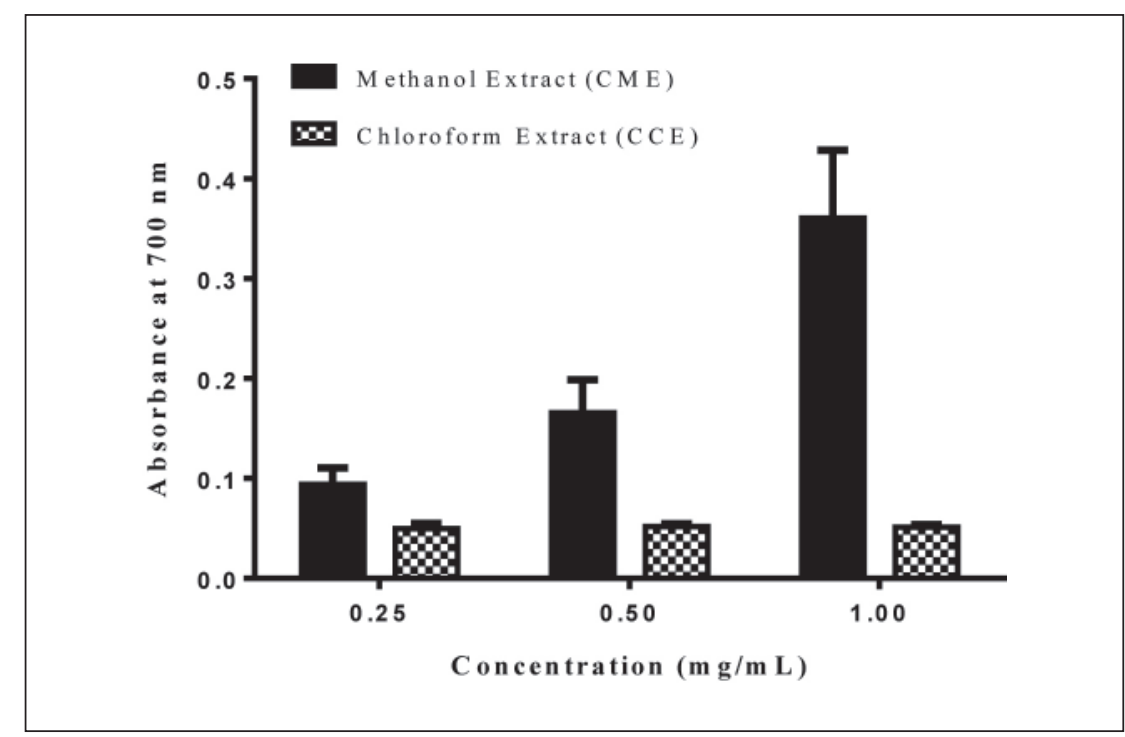

Fig. 1. Reducing power at $700 \mathrm{nM}$ for CME and CCE of $P$. maculata. (mean $\pm \mathrm{SD}$ ).

absorbance value $(0.051 \pm 0.003)$ despite increased extract concentration. In a previous study, the reducing power ability was also correlated with the content of the phenolic compounds. The phenolic compound is a suitable electron donor and associated with reducing power property because of the presence of reductones which caused the reduction of $\mathrm{Fe}_{3+} /$ ferricyanide complex to ferrous form (Murugan \& Parimelazhagan 2014).

To elucidate the antioxidant compound present in P. maculata, Tandem Mass Spectrometry Analysis (LC-MS/MS) was conducted on both CME and CCE using a positive mode analysis with a non-targeted approach. The extracts were analyzed and the metabolites were identified with the METLIN database. Based on the profile analysis, 260 compounds were detected in CME and 241 compounds in CCE. Twelve compounds were putatively identified as antioxidants in both CME and CCE (Table 3). In both extracts, uric acid was detected and dominantly present in CME. In addition to uric acid, five more antioxidant compounds were putatively identified in CME.
The compounds were delphinidin 3,5-di(6-omalonylglucoside), theaflavin, dalpanin, pelargonidin 3 - o - [ b - d - g l u c o p y r a n o s y 1 - ( 1 - > 2) - [ 4 hydroxycinnamoyl-(->6)]-b-d-glucopyranoside](e-) 5-o-(6-o-malonyl-b-d-glucopyranoside) and pelargonidin 3-(6''-p-coumarylglucoside)-5-(6'"acetylglucoside). On the other hand, gallocatechin( 4 alpha->8)-gallocatechin-( 4 alpha- $>8)$ gallocatechin, epiafzelechin $(2 \mathrm{R}, 3 \mathrm{R})(-), 3,3^{\prime}$-di-Ogalloylpro delphinidin B5, 8-prenylkaempferol3rhamnosyl-(1->3)-[apiosyl-(1->6)-glucoside] and $[3,5,7,4$ '-tetrahydroxyflavan-(4->8) $] 2-3,4,5,7,4$ 'pentahydroxyflavan were identified in CCE. Although both extracts possess a similar numbers of antioxidant compounds, the overall antioxidant activity of CME was higher than CCE based on Folin Ciocalteu, DPPH, and reducing power assay. Differences in antioxidant activity between the CME and CCE extracts may be due to the relative abundance of compounds indicated by the peak intensity. For example, peak intensity values of uric acid in CME were 75129 while in CCE, it was only 1899. 


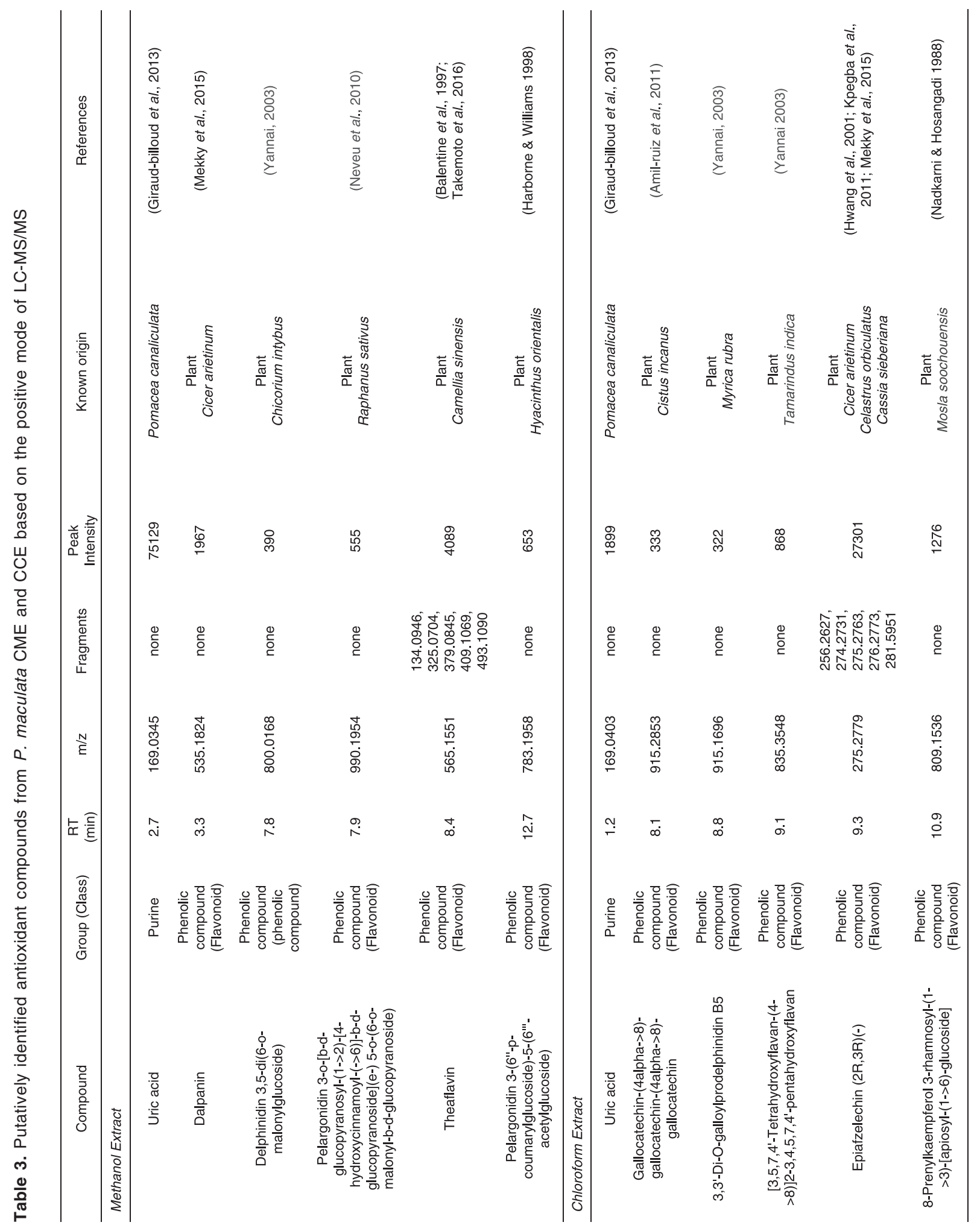




\section{DISCUSSION}

The mollusc is exposed to various environmental conditions that can induce fatal oxidative stress that reduces the snail survivability. To reduce the damage caused by oxidative stress, the mollusk depends on both enzymatic and non-enzymatic antioxidant agents (Giraud-Billoud et al., 2013). The study also demonstrated that the mollusk antioxidant capacity (reducing capacity) is due to the presence of phenolic compounds (Murugan \& Parimelazhagan 2014) which was also demonstrated by the assay performed in this study (Table 1). Total phenolic or reducing compounds were also studied in Cucumaria frondosa (Zhong et al., 2007), Bursatella leachii (Braga 2014) and Malaysian Sea Cucumber Holothuria leucospilota (Ceesay et al., 2019). In our study, reducing capacity of $P$. maculata was significantly demonstrated by crude methanol extract (CME) compared to crude chloroform extract (CCE) with p-value less than 0.05 . The reducing capacity of $P$. maculata $\mathrm{CME}$ and CCE recorded in this study $(43.22 \pm 3.02 \mathrm{mg}$ GAE/g extract and $13.62 \pm 1.92 \mathrm{mg} \mathrm{GAE} / \mathrm{g}$ extract, respectively) has also surpassed the reducing capacity from $B$. leachii, $C$. frondosa and $H$. leucospilota of previous studies $(7.5 \pm 0.1 \mathrm{mg}$ $\mathrm{GAE} / \mathrm{g}$ extract, $1.00 \pm 0.00 \mathrm{mg} \mathrm{GAE} / \mathrm{g}$ and $4.58 \pm 0.002$ mg GAE/g, respectively).

Several studies suggested that the total phenolic content of different invertebrates was due to their preferences on a selective diet (Mamelona et al., 2007; Zhong et al., 2007; Braga, 2014). For example, B. leachii and $C$. frondosa were known to consume algae that contained a low concentration of phenolic compounds. However, P. maculata is a ferocious eater and consumes a variety of macrophytes and plant (Hussain 2006; Hayes et al., 2015) which consist of higher phenolic content than algae ranging from 9.02 to $28.39 \mathrm{mg} / \mathrm{g}$ dry weight and 0.95 to $10.68 \mathrm{mg} / \mathrm{g}$ dry weight; respectively (Li et al., 2007; Bøezinová \& Vymazal, 2018).

The scavenging activity of CME and CCE were also correlated to phenolic compounds (Singh et al., 2016). Based on current study, CME exhibits higher scavenging activity compared to CCE. This may be due to higher phenolic compounds or reducing compounds that scavenge DPPH radical in $\mathrm{CME}$ compared to $\mathrm{CCE}$. Current findings are also supported by previous study done on $P$. ampullacea. Based on DPPH scavenging activity, the IC50 value of $P$. ampullacea CME $(0.111 \mathrm{mg} /$ $\mathrm{ml}$ ) is lower than CCE $(0.997 \mathrm{mg} / \mathrm{ml})$ (Haslianti et al., 2017). Besides, Borquaye et al. (2016) also performed a DPPH scavenging activity towards Littorina littorea and Galatea paradoxa. In their study, CME of G. paradoxa $(0.37 \mathrm{mg} / \mathrm{ml})$ showed higher scavenging activity of DPPH in comparison to L. littorea CME $(0.78 \mathrm{mg} / \mathrm{ml})$ (Borquaye et al., 2016). Furthermore, variation in extraction method and time of extraction may also affect the antioxidant content between the studies (Dhanani et al., 2017).

The antioxidant activity of apple snail extract was also investigated by evaluating the extracts reducing power activity. Current study demonstrated that polar extract has higher reducing power activity compared to non-polar extract. Higher reducing power activity by polar extract compared to nonpolar extract was in agreement with a study performed by Nazeer and Naqash (2013). In their study, Loligo duvauceli (L) and Donax cuneatus (D) underwent extraction using ethyl acetate (EA) and diethyl ether (EE). The study reported that LEA extract had higher reducing power activity with value of absorbance 0.07 at $0.5 \mathrm{mg} / \mathrm{ml}$ compared to DEA (0.05), LEE (0.04) and DEE (0.03) of the same concentration. Regardless of solvents used in both studies, the reducing power activity of our polar (CME, 0.17 \pm 0.03 ) and non-polar (CCE, $0.05 \pm 0.003$ ) extracts were comparable to Nazeer and Naqesh (2013).

In order to identify the composition of nonenzymatic antioxidant agents in apple snail $(P$. maculata), LC-MS/MS approach was taken. A total of 12 antioxidant compounds from CME and CCE was detected including the presence of endogenous antioxidant (uric acid) that was more prominent than phenolic compounds in CME (Table 3). It is highly possible that uric acid is the major metabolite that gives CME high antioxidant activity, since uric acid was previously demonstrated to reduce DPPH (Tasaki et al., 2017) and classified as a nonenzymatic antioxidant to combat ROS production after estivation (hypometabolism) in a snail along with reduced glutathione (Giraud-Billoud et al., 2013). During 45 days of estivation, uric acid increased as a consequence of concomitant oxyradical production during uric acid synthesis by xanthine oxidase (Giraud-Billoud et al., 2011). Later, after arousal was induced, uric acid dropped to or near baseline levels within $20 \mathrm{~min}$ and remained low up to $24 \mathrm{~h}$ after arousal induction (Giraud-billoud et al., 2011). In contrast, the presence of uric acid in the current study was not the result of snail aestivation because the snails were collected when they are still active before they are snap-freezed using liquid nitrogen.

As for phenolic compounds in both CME and CCE, the result of the current study is in agreement with previous studies who suggested that the phenolic content in invertebrates is due to the diet of consuming plants rich in phenolic compounds (Mamelona et al., 2007; Zhong et al., 2007; Braga 2014). The phenolic compound is a large class of plant secondary metabolites, showing the diversity 
of structures and act as a defense mechanism including antioxidant properties (Cheynier, 2012). For instance, theaflavin is a phenolic compound isolated from Camellia sinensis. The compounds have been associated with various physiological effects such as anti-obesity, glucose-lowering, anticancer effects as well as antioxidant activity (Leung et al., 2001; Takemoto et al., 2016). A previous study by Leung et al. (2001) on theaflavin had shown that the compound has antioxidant activity by the ability to reduce thiobarbituric acidreactive substances (TBARS). As for dalpanin, it is an isoflavonoid extracted from Cicer arietinum that possesses antioxidant and estrogenic activities (Mekky et al., 2015).

Pelargonidin and delphinidin are anthocyanins, which is a subgroup of water-soluble flavonoids. Anthocyanin naturally occurs in plants and is responsible for many of the colors observed in nature. Anthocyanin acts as photoprotectants by scavenging free radicals that are produced during photosynthesis (Sui, 2017). In this study, there are two compounds that putatively identified as pelargonidin which are pelargonidin 3-(6''-pcoumarylglucoside)-5-(6'"'-acetylglucoside) and pelargonidin 3-o-[b-d-glucopyranosyl-(1->2)-[4hydroxycinnamoyl-(->6)]-b-d-glucopyranoside](e-) 5-o-(6-o-malonyl-b-d-glucopyranoside $)$. Pelargonidin 3-(6'"-p-coumarylglucoside)-5-(6'”acetylglucoside) is found in red flower of Hyacinthus orientalis meanwhile pelargonidin 3o - [ b - d - g 1 u c o p y r a n o s y $1-(1->2)$ - [ 4 hydroxycinnamoyl-(->6)]-b-d-glucopyranoside](e-) 5-o-(6-o-malonyl-b-d-glucopyranoside) is found in Raphanus sativus (Harborne \& Williams 1998).

Despite phenolic compound availability, the antioxidant activity of CCE in the respective assays were less than CME. In CCE, epiafzelechin was the most prominent phenolic compound followed by uric acid. However, the epiafzelechin compound was previously isolated using polar solvent (Kpegba et al., 2011). Thus, the compound that was putatively identified in CCE may not be epiafzelechin and did not have antioxidant activity as shown by Kpegba et al. (2011).

Other flavonoid compounds detected in $\mathrm{CCE}$ was 8-prenylkaempferol 3-rhamnosyl-(1->3)[apiosyl-(1->6)-glucoside] and [3,5,7,4'tetrahydroxy flavan-(4->8) ] 2-3,4,5,7,4' pentahydroxyflavan. The former is classified as flavonoid glycoside while the latter belongs to biflavonoids and polyflavonoid subclass (Nassar et al., 2013; Sandesh et al., 2014). As for gallocatechin-(4 alpha->8)-gallocatechin-(4 alpha$>8$ )-gallocatechin and 3,3'-Di-O-galloylprodelphinidin B5, both compounds were classified as anthocyanidin that can be isolated from Cistus incanus and Myrica rubra, respectively (Harborne \& Williams 1998). All compounds were known to display antioxidant activity. Therefore, antioxidant capacity of apple snail extract may not be due to the presence of phenolic compounds only, but also contributed by non-enzymatic products of the snail metabolism.

\section{CONCLUSION}

In this study, we conclude that non-enzymatic antioxidant compounds present in $P$. maculata consist of uric acid and phenolic compounds such as theaflavin and Epiafzelechin. The antioxidant activity was most prominent in polar extract and highly abundant with uric acid, followed by phenolic compounds such as theaflavin, dalpanin, pelargonidin and delphinidin. The presence of phenolic compounds were highly likely accumulated from the snail diet, and play an important role to balance the organism oxidative stress and retain its survival.

\section{ACKNOWLEDGEMENTS}

We would like to thank the Department of Biological Sciences and Biotechnology, Faculty of Science and Technology, Analytical Lab of Institute of Biology Systems (INBIOSIS), Centre for Research and Instrumentation Management (CRIM) and Universiti Kebangsaan Malaysia for the research facility and infrastructure. We are also thankful to UKM for the funding of the research (GGPM2016-013). We also would like to thank Dr. Lim Seng Joe, Aninah Mohamad Hanapiah, Norhabshah Abdul Jalil, Afnani Alwi, and Nurul Shahirah Aziz for their assistance and contribution in this research.

\section{REFERENCES}

Amil-ruiz, F., Blanco-portales, R., Munoz-Blanco, J. \& Caballero, J.L. 2011. The strawberry plant defense mechanism: A Molecular Review Review. Plant Cell Physiology, 52(11): 18731903.

Baker, P., Zimmanck, F. \& Baker, S.M. 2010. Feeding rates of an introduced freshwater gastropod Pomacea Insularum on Native and nonindigenous aquatic plants in Florida. Journal of Molluscan Studies, 76: 138-143.

Balentine, D.A., Wiseman, S.A., Bouwens, L.C.M., Balentine, D.A., Wiseman, S.A. \& Bouwens, L.C.M. 1997. The chemistry of tea flavonoids. Critical Reviews in Food Science and Nutrition, 37(8): 693-704. 
Borquaye, L.S., Darko, G., Ocansey, E. \& Ankomah, E. 2015. Antimicrobial and antioxidant properties of the crude peptide extracts of Galatea paradoxa and Patella rustica. SpringerPlus, 4(1): 2-7.

Borquaye, L.S., Darko, G., Oklu, N., Anson-Yevu, C. \& Ababio, A. 2016. Antimicrobial and antioxidant activities of ethyl acetate and methanol extracts of Littorina littorea and Galatea paradoxa. Cogent Chemistry, 2(1): 110.

Bose, U., Centurion, E., Hodson, M.P., Shaw, P.N., Storey, K.B. \& Cummins, S.F. 2016. Global metabolite analysis of the land snail Theba pisana hemolymph during active and aestivated states. Comparative Biochemistry and Physiology - Part D: Genomics and Proteomics, 19: 25-33.

Braga, F.F.R. 2014. Evaluation of the antioxidant activity and antitumour activity of marine invertebrates extracts (MSc). Universidade do Algarve. International Letters of Natural Sciences, 34: 42-61.

Bøezinová, T.D. \& Vymazal, J. 2018. Phenolic compounds in wetland macrophytes. Scientia Agriculturae Bohemica, 1: 1-8.

Burlakova, L., Karatayev, A., Padilla, D., Cartwright, L. \& Hollas, D. 2009. Wetland restoration and invasive species: Apple snail (Pomacea insularum) feeding on native and invasive aquatic plants. Restoration Ecology, 17(3): 433440.

Cheynier, V. 2012. Phenolic compounds/: from plants to foods. Phytochemistry Reviews, 11(23): 153-177.

Dhanani, T., Shah, S., Gajbhiye, N.A. \& Kumar, S. 2017. Effect of extraction methods on yield, phytochemical constituents and antioxidant activity of Withania somnifera. Arabian Journal of Chemistry, 10: 1193-1199.

Dreon, M.S., Schinella, G., Heras, H. \& Pollero, R.J. 2004. Antioxidant defense system in the apple snail eggs, the role of ovorubin. Archives of Biochemistry and Biophysics, 422(1): 1-8.

Gayathri, M., Ramasamy, M. \& Santhiya, N. 2017. Extraction, identification of bioactive compounds and in vitro antioxidant activity potential in freshwater Ampullariidae snail Pila virens. International Journal of Fisheries and Aquatic Research, 2(2): 1-7.

Giraud-billoud, M., Abud, M.A., Cueto, J.A., Vega, I.A. \& Castro-vazquez, A. 2011. Uric acid deposits and estivation in the invasive applesnail, Pomacea canaliculata. Comparative Biochemistry and Physiology, Part A, 158(4): 506-512.
Giraud-Billoud, M., Vega, I.A., Tosi, M.E.R., Abud, M.A., Calderon, M.L. \& Castro-Vazquez, A. 2013. Antioxidant and molecular chaperone defences during estivation and arousal in the South American apple snail Pomacea canaliculata. Journal of Experimental Biology, 216(4): 614-622.

Harborne, J.B. \& Williams, C.A. 1998. Anthocyanins and other flavonoids. Natural Product Reports, 15: 631-652.

Haslianti, Inthe, M.G. \& Ishak, E. 2017. Karakteristik keong kowoe dan aktivitas antioksidannya. Jurnal Pengolahan Hasil Perikanan Indonesia, 20(1): 74-83.

Hayes, K.A., Burks, R.L., Castro-Vazquez, A., Darby, P.C., Heras, H., Martín, P.R., Qiu, J.-W., Thiengo, S.C., Vega, I.A., Wada, T., Yusa, Y., Burela, S., Cadierno, M.P., Cueto, J.A., Dellagnola, F.A., Dreon, M.S., Frassa, M.V., Giraud-Billoud, M., Godoy, M.S., Ituarte, S., Koch, E., Matsukura, K., Pasquevich, M.Y., Rodriguez, C., Saveanu, L., Seuffert, M.E., Strong, E.E., Sun, J., Tamburi, N.E., Tiecher, M.J., Turner, R.L., ValentineDarby, P.L. \& Cowie, R.H. 2015. Insights from an integrated view of the biology of apple snails (Caenogastropoda: Ampullariidae). Malacologia, 58(1\&2): 245-302.

Hayes, K.A., Cowie, R.H., Thiengo, S.C. \& Strong, E.E. 2012. Comparing apples with apples: Clarifying the identities of two highly invasive neotropical Ampullariidae ( Caenogastropoda). Zoological Journal of the Linnean Society, 166(4): 723-753.

Hermes-Lima, M. \& Storey, K.B. 1995. Antioxidant defenses and metabolic depression in a pulmonate land snail. American Journal of Physiology-Regulatory, Integrative and Comparative Physiology, 268(6): R1386-R1393.

Hussain, Y. 2006. Pengurusan siput gondang emas di Malaysia. Buletin Teknologi Tanaman, 3: 6170 .

Hussain, Y., Amzah, B., Sivapragasam, A., Nordin, M., Hisham, M.N.M. \& Misrudin, H. 2017. Invasive apple snails in Malaysia. In: Biology And Management of Invasive Apple Snails. R.C. Joshi, R.H. Cowie and L.S. Sebastian (Eds.). Philippine Rice Research Institute, Manila. 169195 pp.

Hwang, B.Y., Kim, H.S., Lee, J.H., Hong, Y.S., Ro, J.S., Lee, K.S. \& Lee, J.J. 2001. Antioxidant benzoylated flavan-3-ol glycoside from Celastrus orbiculatus. Journal of Natural Products, 64: 82-84. 
Kpegba, K., Agbonon, A., Petrovic, A.G., Amouzou, E., Gbeassor, M., Proni, G. \& Nesnas, N. 2011. Epiafzelechin from the root bark of Cassia sieberiana: Detection by DART mass spectrometry, spectroscopic characterization, and antioxidant properties. Journal of Natural Products, 74: 455-459.

Leung, L.K., Su, Y., Chen, R., Zhang, Z., Huang, Y. \& Chen, Z. 2001. Theaflavins in black tea and catechins in green tea are equally. American Society for Nutritional Sciences, 2248-2251.

Li, H. Bin, Cheng, K.W., Wong, C.C., Fan, K.W., Chen, F. \& Jiang, Y. 2007. Evaluation of antioxidant capacity and total phenolic content of different fractions of selected microalgae. Food Chemistry, 102(3): 771-776.

Magalhães, L.M., Segundo, M.A., Reis, S. \& Lima, J.L. 2008. Methodological aspects about in vitro evaluation of antioxidant properties. Analytica Chimica Acta, 613(1): 1-19.

Mamat, S.F., Azizan, K.A., Baharum, S.N., Noor, N.M. \& Aizat, W.M. 2018. ESI-LC-MS basedmetabolomics data of mangosteen (Garcinia mangostana Linn.) fruit pericarp, aril and seed at different ripening stages. Data in Brief, 17: 1074-1077.

Mamelona, J., Pelletier, É., Girard-Lalancette, K., Legault, J., Karboune, S. \& Kermasha, S. 2007. Quantification of phenolic contents and antioxidant capacity of Atlantic sea cucumber, Cucumaria frondosa. Food Chemistry, 104(3): 1040-1047.

Mekky, R.H., Contreras, M. del M., El-Gindi, M.R., Abdel-Monem, A.R., Essam, A.-S. \& SeguraCarretero, A. 2015. Profiling of phenolic and other compounds from Egyptian cultivars of chickpea (Cicer arietinum L.) and antioxidant activity/: a comparative study. RSC Advances, 5: 17751-17767.

Mensor, L.L., Menezes, F.S., Gilda, G.L., Alexandre, S.R., Tereza, C.D.S., Cintia, S.C. \& Suzana, G.L. 2001. Screening of Brazilian plant extracts for antioxidant activity by the use of DPPH free radical method. Phytotherapy Research, 15: 127-130.

Murugan, R. \& Parimelazhagan, T. 2014. Comparative evaluation of different extraction methods for antioxidant and anti-inflammatory properties from Osbeckia parvifolia Arn. - An in vitro approach. Journal of King Saud University - Science, 26(4): 267-275.

Nadkarni, S.S. \& Hosangadi, B.D. 1988. Studies in large ring compounds. Part IX. Observations on cyclodehydration of anthraniloylanthranilic acids. Indian Journal of Chemistry, Section B, 27B(3): 225-228.
Nassar, M.I., Aboutabl, E.A., Eskander, D.M., Grace, M.H. \& Sleem, A.A. 2013. Flavonoid glycosides and pharmacological activity of Amphilophium paniculatum. Pharmacognosy Research, 5(1): 17-21.

Nazeer, R.A. \& Naqash, S.Y. 2013. In vitro antioxidant activity of two molluscs, Loligo duvauceli Orbigny and Donax cuneatus Linnaeus, by solvent extraction methods. Mediterranean Journal of Nutrition and Metabolism, 6(1): 17-21.

Neveu, V., Perez-Jimenez, J., Vos, F., Crespy, V., Chaffaut, L., Mennen, L., Knox, C., Eisner, R., Cruz, J., Wishart, D. \& Scalbert, A. 2010. Phenol-Explorer/: an online comprehensive database on polyphenol contents in foods. Database, 2010: bap024.

Ochi, M., Kataoka, K., Ariki, S., Iwatsuki, C., Kodama, M. \& Fukuyama, Y. 1998. Antioxidative Bromoindole derivatives from the mid-intestinal gland of the muricid gastropod Drupella fragum. Tetrahedron, 61: 1043-1045.

Okada, Y., Okajima, H., Konishi, H., Terauchi, M., Ishii, K., Liu, I.M. \& Watanabe, H. 1990. Antioxidant effect of naturally occurring furan fatty acids on oxidation of linoleic acid in aqueous dispersion. Journal of the American Oil Chemists' Society, 67(11): 858-862.

Overy, S.A., Walker, H.J., Malone, S., Howard, T.P., Baxter, C.J., Sweetlove, L.J., Hill, S.A. \& Quick, W.P. 2005. Application of metabolite profiling to the identification of traits in a population of tomato introgression lines. Journal of Experimental Botany, 56(410): 287-296.

Pachaiyappan, A., Muthuvel, A., Sadhavisam, G., Sankar, V.J., Sridhar, N. \& Kumar, M. 2014. In vitro antioxidant activity of different gastropods, bivalves and echinoderm by solvent extraction method. International Journal of Pharmaceutical Sciences and Research, 5(6): 2529-2535.

Phaniendra, A., Jestadi, D.B. \& Periyasamy, L. 2015. Free radicals: Properties, Sources, targets, and their implication in various diseases. Indian Journal of Clinical Biochemistry, 30(1): 11-26.

Salleh, N.H.M., Arbain, D., Daud, M.Z.M., Pilus, N. \& Nawi, R. 2012. Distribution and management of Pomacea canaliculata in the Northern Region of Malaysia: Mini Review. APCBEE Procedia, 2: 129-134.

Sandesh, P., Velu, V. \& Singh, R.P. 2014. Antioxidant activities of tamarind (Tamarindus Indica) seed coat extracts using in vitro and in vivo models. Journal of Food Scince and Technology, 51: 1965-1973. 
Singh, G., Passsari, A.K., Leo, V.V., Mishra, V.K., Subbarayan, S., Singh, B.P., Kumar, B., Kumar, S., Gupta, V.K., Lalhlenmawia, H. \& Nachimuthu, S.K. 2016. Evaluation of phenolic content variability along with antioxidant, antimicrobial, and cytotoxic potential of selected traditional medicinal plants from India. Frontiers in Plant Science, 7: 407.

Sui, X. 2017. Impact of Food Processing on Anthocyanins. Springer, Singapore.

Takemoto, M., Takemoto, H. \& Saijo, R. 2016. Theaflavin synthesized in a selective, dominotype, one-pot enzymatic biotransformation method with Camellia sinensis cell culture inhibits weight gain and fat accumulation to high-fat diet-induced obese mice. Biological and Pharmaceutical Bulletin, 39(8): 1347 1352.

Tamil Muthu, P. \& Selvaraj, D. 2015. Analysis of bioactive constituents from the flesh of Turbo brunneus (Roding, 1798) by GCMS. International Journal of Fisheries and Aquatic Studies, 3(1): 257-259.
Tasaki, E., Sakurai, H., Nitao, M., Matsuura, K. \& Iuchi, Y. 2017. Uric acid, an important antioxidant contributing to survival in termites. PLoS ONE, 12(6): e0179426.

Vassilev, N.G., Simova, S.D., Dangalov, M., Velkova, L., Atanasov, V., Dolashki, A. \& Dolashka, P. 2020. An ${ }^{1} \mathrm{H}$ NMR-and MS-based study of metabolites profiling of garden snail Helix aspersa mucus. Metabolites, 10(9): 1-15.

Yannai, S. 2003. Dictionary of Food Compounds with CD-ROM. Chapman and Hall/CRC, New York.

Zhong, Y., Khan, M.A. \& Shahidi, F. 2007. Compositional characteristics and antioxidant properties of fresh and processed sea cucumber (Cucumaria frondosa). Journal of Agricultural and Food Chemistry, 55(4): 1188-1192. 